\title{
血栓溶解用擋找器開発に関する基礎研究
}

\author{
森田 実 \\ 山口大学大学院理工学研究科システム工学専攻博士後期過程
}

\section{1. 研究背景}

人体の血管内で生じる病的血栓は脳梗塞の原因として重 要である. 血栓症の死亡率や後遺症発生率は血管を再疎通さ せる迄の時間によって左右され1)-2), 素早い血栓の治療が求 められている. 現在血栓治療として, 超音波振動を利用した 手法が研究され検討されているが, 脳血管内でキャビテーシ ヨンを考慮する必要があり, 出力の調整が必要となる。こう した背景から，本研究では効果的に血栓を擋找するための， 血管内に挿入可能なマイク口搅找器の開発を目指している. 本論文では, 擋找器の性能をFEM解析により推定し, 擋拌 効果の向上を目指す設計をするものである.

\section{2. 擋拌器の基本構造と解析結果}

擋拌器は変位を拡大するための構造物に, 圧電素子を貼り 付けた構造である. 本論文では Fig. 1 の基本的な梁型擋䢁器 (a) と，新たに設計したヒンジ型擋找器(b)について擋找実験 結果を示す.ヒンジ型撹找器は, 擋找器の発生力を高めるよ う設計され, 梁型擋汼器よりも流体中での大きな振幅が期待 される。

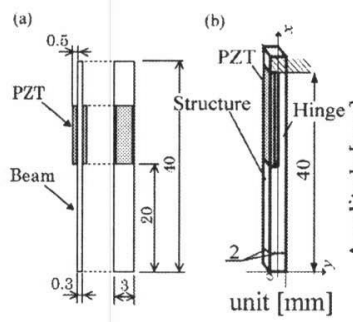

(c)

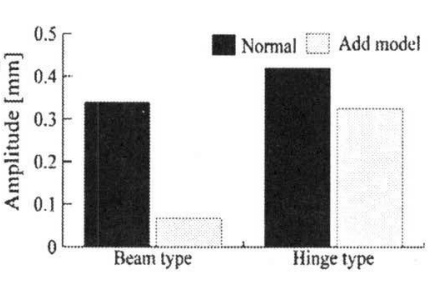

Fig. 1 Schematic drawing of beam (a) and Hinge (b) type stirrers. Analytical results of amplitude of stirrer tip (c).

FEM 解析は専用ソフト(ANSYS)を用いて行う。本解析は 流体中や, ごく微小な振動が計算可能で，複雑かつ小型の装 置も簡単にその動作を計算可能なため, マイクロ擋汼器の開 発に必須であるといえる. Fig. 1(c) は各擋找器の空気中 (Normal)と流体中(Add Model)の振幅を計算した結果であ る. 結果から, 発生力の高いヒンジ型擋汼器は流体中で振幅 の減少が少なく, 高い効果が期待できる.

\section{3. 擋拌実験}

摚找効果の計測は, 先行研究において確立した方法を用い ており, 摚汼対象の濃度を計測可能である3). 擋找対象はFig. 2(c)の色付けした水とグリセリンの 2 層流体である. グリセ リンは水に溶かすことで血液と同等の粘性を表現すること ができ, 原液は血液の 200 倍の粘性を持つため, 溶解剤によ
る溶解初期の血栓の粘性と仮定している. 摚汼時間は 30 分 間, 圧電素子に入力する周波数は梁型では $482 \mathrm{~Hz}$, ヒンジ型 では $402 \mathrm{~Hz}$ の矩形波とし, 各擋找器で電力を統一している. 空気中での擋䢁器の先端振幅は梁型が約 $600 \mu \mathrm{m}$, ヒンジ型 が約 $250 \mu \mathrm{m}$ である. 擋汼器の性能確認のため, 空気中と流 体中で擋䢁器の先端から 17 19mmで振幅を計測した結果を Fig. 2 に示す. 結果からヒンジ型擋抖器は流体負荷による振 幅減少が少なく, 流体中で変位と発生力を共に高められてい ることが確認できる. 摚找効果を比較した結果をFig. 2(b), (c) に示す. 結果から, ヒンジ型擋抖器の高い効果が示され, 発 生力を高めることの有効性を示すことができた.

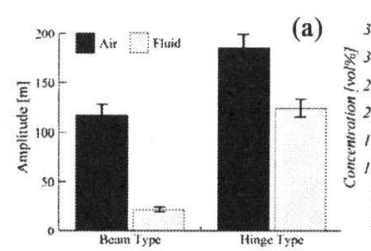

(b)
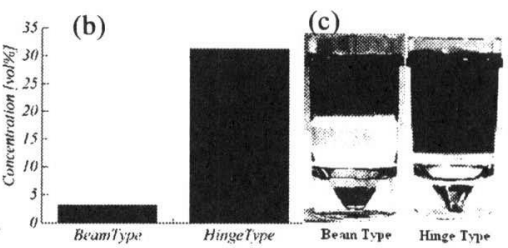

Fig. 2 Displacement result of several stirrers. Measuring position is 17 to $19 \mathrm{~mm}$ from stirrer tip (a). Concentration of dissolved glycerol for stirring (b) and photographs of testing liquid after stir (c).

\section{4. 結論}

FEM 解析により流体中の撹挥器の動作を計算することで, 新たに設計した擋拌器の効果を推定した。設計した撹拌器は 実験によりその高い性能を確認できた。ヒンジ型擋汼器は積 層圧電素子を用いることで, さらに 50 倍以上の性能を示す ことも, 解析により確認されていることから, 今後は擋挥器 の実用化を目指し，小型高性能化を図る．また，血栓摚拌に よる血液の動きをシミュレートすることで, 血栓溶解を増進 する擋挥器の動作について見当をしていきたい.

\section{参考文献}

1) Katzan L.I., Furlan J.A., Lloyd E.L. et al, "Use of tissue-type plasminogen activator for acute ischemic stroke: the Cleveland area experience", JAMA, 283: 1151-1158, 2000.

2) Albers W.G., Bates E.V., Clark M.W, et al, "Intravenous Tissue-Type Plasminogen Activator for Treatment of Acute Stroke", JAMA 283, pp. 1145-1150, 2000.

3) Zhongwei J., Minoru M. Michiyasu S., et al, "Study on In-vivo Measuring Method of Solubility for Cerebral Thrombus Dissolution", IJAEM, Vol.24, p225-234, 2006. 